\title{
Impact of the invasive alien plant Solidago gigantea on primary productivity, plant nutrient content and soil mineral nutrient concentrations
}

\author{
Sonia Vanderhoeven · Nicolas Dassonville • \\ Lydie Chapuis-Lardy · Matthieu Hayez • \\ Pierre Meerts
}

Received: 18 January 2006/ Accepted: 16 May 2006/Published online: 15 August 2006

(C) Springer Science+Business Media B.V. 2006

\begin{abstract}
Invasion by alien plants can alter ecosystem processes and soil properties. In this study, we compared aboveground productivity, nutrient pools in standing biomass and topsoil $(0-0.10 \mathrm{~m})$ mineral nutrient concentrations between plots invaded by Early Goldenrod (Solidago gigantea) and adjacent, uninvaded, vegetation at five sites in Belgium. The five sites were characterised by a resident perennial herbaceous vegetation and spanned a wide range in soil fertility level and floristic composition. Invaded stands consistently had higher (2-3-fold) aboveground productivity and lower mineral element concentrations in standing phytomass. Nutrient pools (calculated as concentration $\times$ phytomass) was ca. twice higher in invaded plots, suggesting that $S$. gigantea might enhance nutrient cycling rates. Impacts on topsoil chemistry were surprisingly modest, with slightly
\end{abstract}

Equally contributing authors: S. Vanderhoeven and N. Dassonville

S. Vanderhoeven $\cdot$ N. Dassonville .

L. Chapuis-Lardy · M. Hayez · P. Meerts

Laboratory of Plant Genetics and Ecology, Free

University of Brussels, 1850, chaussée de Wavre,

B-1160, Bruxelles, Belgium

S. Vanderhoeven $(\square)$

Laboratory of Ecology, Gembloux

Agricultural University, Passage des Déportés,2,

B-5030 Gembloux, Belgium

e-mail: sonia.vanderhoeven@belgacom.net higher nutrient concentrations under the invader. A noticeable exception was phosphorus, which showed higher concentrations of ammonium acetate-extractable fraction in invaded plots in four of five sites. It appears that $S$. gigantea does not significantly contribute to nutrient uplift from deep soil layers to topsoil, possibly because it does not root much deeper compared to resident vegetation.

Keywords Invasive alien species · Soil nutrients · Nutrient pools $\cdot$ Phosphorus $\cdot$ Solidago gigantea
Abbreviations
CEC Cation exchange capacity
Bs base saturation rate

\section{Introduction}

Besides the well-documented alteration of community composition and dynamics, exotic plant invasions are known to modify key ecosystem processes in subtle way (Ehrenfeld 2003; Levine et al. 2003). As plant traits and ecosystem processes are closely connected (Chapin et al. 2002; Hobbie 1992; Van Breemen and Finzi 1998), the substitution of dominant exotics for native species may result in alterations in biogeochemical 
cycles and soil chemistry (Ehrenfeld and Scott 2001).

In her review focussing on soil nutrient cycling processes, Ehrenfeld (2003) pointed out that invasive species often increased biomass and net primary productivity of ecosystems, increased $\mathrm{N}$ availability, altered $\mathrm{N}$ fixation rates and produced litter with higher decomposition rates than co-occurring native species. Besides the existence of general patterns, direction and amplitude of impacts depend on local abiotic conditions as well as on the composition of the native community (Bolton et al. 1990; Evans et al. 2001; Scott et al. 2001). However, most published work has examined impacts of exotics at a single site (but see Hook et al. 2004). Moreover, studies have been mainly concerned with carbon and nitrogen and comparatively less attention has been paid to other elements (but see Blank and Young 2002, 2004; Vanderhoeven et al. 2005). It is still well known that plants can influence the availability of other elements, including $\mathrm{P}$, by species-specific processes (Chapin et al. 2002; Grierson and Adams 2000; Mitchell et al. 1997).

Belgium and neighbouring countries have suffered from invasion by exotic plants, which have dramatically increased their range in the last 30 years (Muller 2000; Verloove 2002). Solidago gigantea Aiton (Early Goldenrod) is one of the most troublesome invaders in this area. It is a rhizomatous perennial herb native of North America. It was introduced in Europe in the 18th century as an ornamental and melliferous plant and became invasive some 100 years later (Wagenitz 1964). It is known to have a broad tolerance to light, temperature, soil moisture and chemical properties (Weber and Jakobs 2005). It has high invasive success in ruderal and riverside habitats, forming dense mono-specific patches (Weber 1998) and preventing the establishment of native species (Weber 2003). Moreover, along a latitudinal gradient in Europe, it shows clinal variation in phenology and life-history traits (Weber and Schmid 1998).

As proposed by Walker and Smith (1996), the most realistic way to measure the impact of an invader is to compare invaded sites with nearby control sites with similar vegetation, soil, geology, climate and land-use history. In one of the first evaluations of impacts of alien invasive plants on soil in Europe, Vanderhoeven et al. (2005) found higher concentrations of bioavailable nutrients in topsoil under five invasive plants. S. gigantea was one of the five target species but the assessment of its own impact was of relative extent as only one site was considered. On the other hand, Chapuis-Lardy et al. (in press) showed increased $\mathrm{P}$ availability in three sites invaded by $S$. gigantea but they did not considered neither the effects on other soil nutrients nor the nutrient contents and pools in the phytomass. Recently, Güsewell et al. (2005) focussed on one ecosystem of high conservation value, a lakeshore wetland, where they did not find any impact of $S$. gigantea on total soil $\mathrm{N}$ and $\mathrm{P}$.

In this paper, we examine the effects of the invasion of Solidago gigantea on topsoil chemistry, primary productivity and nutrient pools in standing biomass. The comparison is replicated in five sites spanning contrasting floristic composition of the resident vegetation in Belgium. We addressed the following questions: (1) What are the impacts of $S$. gigantea on mineral nutrient concentrations in soil? (2) Are impacts on soil correlated with impacts on nutrients pools in the standing biomass? (3) Do impacts differ in direction and amplitude according to invaded site?

\section{Materials and methods}

Site selection

The 5 selected sites are Kra (Kraainem,

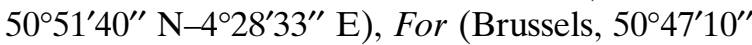
$\left.\mathrm{N}-4^{\circ} 25^{\prime} 33^{\prime \prime} \mathrm{E}\right), \quad$ Gul (Brussels, 50 $47^{\prime} 10^{\prime \prime} \mathrm{N}-$ $\left.4^{\circ} 25^{\prime} 07^{\prime \prime} \mathrm{E}\right), \quad$ Ghi (St-Ghislain, 50 $27^{\prime} 30^{\prime \prime} \mathrm{N}-$ $\left.3^{\circ} 50^{\prime} 25^{\prime \prime} \mathrm{E}\right)$ and Mar (Marche-les-Dames, $50^{\circ} 27^{\prime} 30^{\prime \prime} \mathrm{N}-3^{\circ} 50^{\prime} 25^{\prime \prime} \mathrm{E}$ ). Selected sites fulfilled all the following conditions: (1) well-established, and still increasing populations of $S$. gigantea, (2) sufficiently homogeneous soil, (3) dense patches of $S$. gigantea surrounded by uninvaded vegetation (invaded patches ranged from $25 \mathrm{~m}^{2}$ to more than $100 \mathrm{~m}^{2}$ ). Within site homogeneity of soil was checked by comparing soil profiles topsoil texture between invaded and uninvaded patches. 
Moreover, uninvaded control plots were located as close as possible to the front of expansion of the invader. Thus, site selection sought to minimise the probability of pre-existing differences in soil properties. The same comparative approach was successfully applied to investigate impacts of alien invasive plants by McIntosh et al. (1995), Ehrenfeld et al. (2001), Scott et al. (2001) or more recently by Hook et al. (2004).

In each site, we selected six $1-\mathrm{m}^{2}$ plots in invaded patches and six $1-\mathrm{m}^{2}$ plots in adjacent, uninvaded vegetation. In each plot, the abundance of all vascular plant species was estimated according to Braun-Blanquet scale (5: 75-100\% abundance, 4: 50-75\%, 3: 25-50\%, 2: 5-25\%, 1: $1-5 \%,+:<1 \%)$. The mean abundance of each species was calculated for invaded and uninvaded plots, based on the median value of each class (i.e. $87.5,62.5,37.5,15,3$ and $0.5 \%)$. Mean abundance was then back-transformed into Braun-Blanquet coefficients.

\section{Soil sampling and analyses}

Soil was sampled from February to April before vegetation period. In each plot, five soil cores (0-0.10 m depth, litter discarded) were collected with a soil borer $(0.04 \mathrm{~m}$ in diameter $)$. One core was taken at each corner and one core at the centre of the square. The five cores were then mixed up into a single bulk sample for each plot. In the uninvaded patches, cores were not taken under any particular species. Rather, they were collected under the multispecies vegetation. Soil samples were air-dried until constant weight, and sieved $(<0.002 \mathrm{~m})$. The following parameters were assessed for each sample: soil $\mathrm{pH}$ (stiff paste soil- $\mathrm{H}_{2} \mathrm{O}$ and stiff paste soil- $\mathrm{KCl}$ ), exchangeable acidity and exchangeable aluminium $(1 \mathrm{M} \mathrm{KCl}$ extraction; derivative titration curve for $\mathrm{H}^{+}$and $\mathrm{Al}^{3+}$ for acidic soils), exchangeable cations, available $\mathrm{P}$ and trace elements $\left(1 \mathrm{M} \quad \mathrm{CH}_{3}\right.$ $\mathrm{COONH}_{4} \mathrm{pH} 4.65$ extraction), ICP-AES determination of $\mathrm{Ca}$ (except for carbonated soils) $\mathrm{Mg}$, $\mathrm{K}, \mathrm{Mn}, \mathrm{P}, \mathrm{Cu}$ and $\mathrm{Zn}$. Cation exchange capacity $\left(\mathrm{CEC}=\left[\mathrm{Ca}^{2+}\right]+\left[\mathrm{K}^{+}\right]+\left[\mathrm{Mg}^{2+}\right]+\left[\mathrm{H}^{+}\right]+\left[\mathrm{Al}^{3+}\right]\right)$ and base saturation rate $(\mathrm{Bs})$ were thereafter computed $\left(\mathrm{Bs}=\left(\left[\mathrm{Ca}^{2+}\right]+\left[\mathrm{K}^{+}\right]+\left[\mathrm{Mg}^{2+}\right]\right) / \mathrm{CEC}\right)$ except for carbonated soils. Total $\mathrm{C}$ and $\mathrm{N}$ were assessed using a dry combustion $\mathrm{C} / \mathrm{N}$ analyser (NC-2100, Carlo Erba Instruments, Italy). $\mathrm{CaCO}_{3}$ content was assessed after calcination of organic matter at $450^{\circ} \mathrm{C}$ (dry combustion, Ströhlein dosimeter). Organic $\mathrm{C}$ content $\left(\mathrm{C}_{\mathrm{org}}\right)$ was calculated as (total $\mathrm{C}$-carbonate $\mathrm{C}$ ). Organic matter content $(\mathrm{OM})$ was then calculated as $2 \times \mathrm{C}_{\text {org }}$. Potential nitrogen availability was assessed by in vitro mineralisation: fresh soil samples (sieved at $4 \mathrm{~mm}$ ) were incubated for 6 weeks, at $28^{\circ} \mathrm{C}$ and soil hydratation was kept near field capacity (Lemée 1967). $\mathrm{NO}_{3}-\mathrm{N}$ and $\mathrm{NH}_{4}-\mathrm{N}$ were extracted with $1 \mathrm{~N} \mathrm{KCl}$ and determined colorimetrically with a Technicon analyser.

Aboveground biomass sampling and analyses

Aboveground biomass was harvested in invaded and uninvaded $1 \mathrm{~m}^{2}$ plots in August. Biomass (whole shoot) was oven-dried, weighted and ground with a mill (ZM 100, Retsch, Germany). The samples were ashed in a muffle furnace. Ashes were then dissolved in $1 \mathrm{M} \mathrm{HCl}$ and mineral element concentrations were determined by ICP-AES (Varian Vista MPX). N and $\mathrm{C}$ were assessed using a dry combustion $\mathrm{C} / \mathrm{N}$ analyser (NC-2100, Carlo Erba instruments, Italy). For each element, aboveground nutrient pool was calculated as biomass $\times$ element concentration in the biomass.

\section{Statistical analyses}

For nutrients in soils ( $\mathrm{Ca}, \mathrm{Mg}, \mathrm{K}, \mathrm{Mn}, \mathrm{Zn}, \mathrm{Cu}$ and $\mathrm{P}$ ), $\chi^{2}$ tests were used to compare the proportion of cases showing greater versus lower values in invaded plots with the proportion expected $(50-50 \%)$ under the null hypothesis that invasion has no systematic impact. For each variable, a two-way ANOVA was performed with 'site' and 'invasion' as main effects. In this analysis, a significant 'site $\times$ invasion' interaction indicates that impact of invasion differs according to site. Logarithmic transformation was applied when necessary prior to ANOVA. In case of significant 'invasion' effect or significant 'site $\times$ invasion' interaction, mean values for each site were compared between invaded and uninvaded plots by means of $t$-tests. Bonferroni correction was 
applied based on the number of simultaneous tests for each variable ( $n=5$ sites). Statistical analyses were performed with Statistica 6.1 software (StatSoft Inc. 2003).

\section{Results}

\section{Species composition of vegetation}

Solidago gigantea showed an abundance of at least $75 \%$ in invaded plots of all sites. Species composition differed between invaded and uninvaded plots. The number of species in the community was consistently higher in uninvaded $($ Kra $=40 ;$ For $=5 ;$ Gul $=17 ;$ Ghi $=21 ;$ Mar $=$ 13) compared to invaded plots (Kra =11; For $=4 ; G u l=2 ; G h i=10 ;$ Mar = 5). In site For, however, uninvaded plots were dominated by Urtica dioica.

Soil chemical properties

The five study sites spanned a broad range of soil chemical conditions (Fig. 1). Thus, concentrations of $\mathrm{P}, \mathrm{NO}_{3}-\mathrm{N}$ and $\mathrm{K}$ were 40,20 and $4 \times$ higher at
Fig. 1 Soil chemical composition of invaded and uninvaded plots. Mean values and standard errors for soil $\mathrm{pH}$, exchangeable nutrients $\left(\mathrm{mg} \mathrm{kg}^{-1}\right)$, organic matter (OM: \%), N content (\%), $\mathrm{C} / \mathrm{N}$ ratio, $\mathrm{NH}_{4}^{+}$and $\mathrm{NO}_{3}^{-}$ $\left(\mathrm{mg} \mathrm{kg}^{-1}\right)$. Notice $\log$ scale for $\mathrm{P} . \mathrm{H}^{+}, \mathrm{Al}^{3+}, \mathrm{Ca}$, $\mathrm{CEC}$ and $\mathrm{Bs}$ are not considered here, as they were determined for $<5$ sites. The diagonal black line denotes equal value for invaded and uninvaded plots. Stars refer to significant difference between invaded and uninvaded plots in $t$-tests $(* P<0.05$; $* * P<0.01$ $* * * P<0.001)$. Boxes show the $F$-ratios of the two-way ANOVA performed for the 5 sites with site and invasion (Inv) as main effects (df: site $=4 ;$ Inv $=2$; Site $\times$ Inv $=4$ )
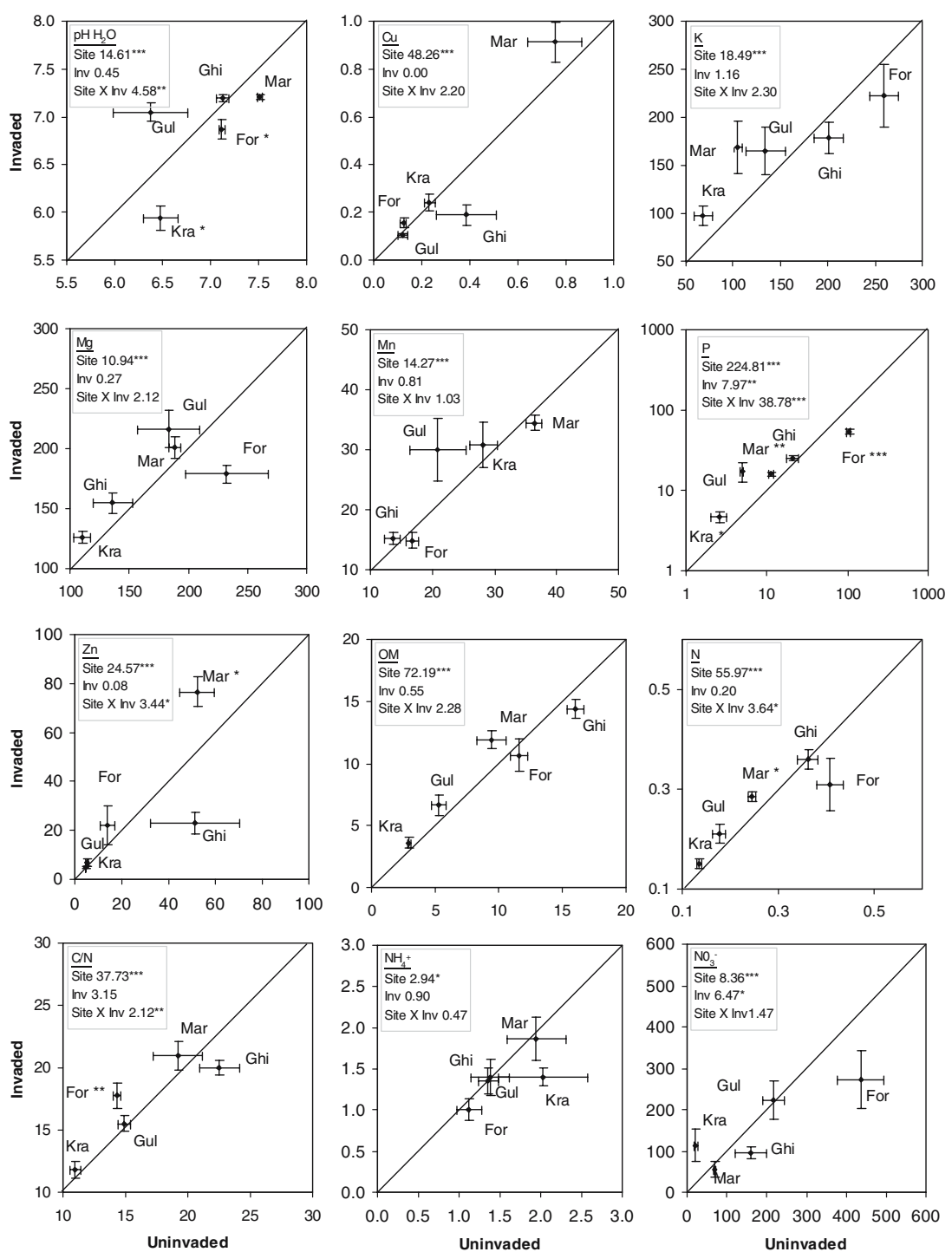
site For compared to site Kra, respectively (Fig. 1). The variation within site due to invasion is low in comparison with variation across the 5 sites. Higher concentrations of nutrients in invaded plots were significantly more frequent than lower concentrations (21 increases of 31 cases; $\left.\chi^{2}=3.90, P<0.05\right)$. The two-way ANOVAs performed on pooled sites (Fig. 1) showed a significant invasion effect for $\mathrm{P}(P<0.001)$ and $\mathrm{NO}_{3}^{-}(P<0.01)$. The 'site' effect was significant for all variables. For 5 variables out of $12\left(\mathrm{pH}_{\mathrm{H} 2 \mathrm{O}}\right.$, $\mathrm{P}, \mathrm{Zn}, \mathrm{N}, \mathrm{C} / \mathrm{N})$, there was a significant 'site $\times$ invasion' interaction, indicating that the impact of invasion varied according to site. The most significant interaction was for P. In contrast to all other sites, site For had significantly lower concentrations of $\mathrm{P}$ under $S$. gigantea.

Impacts can also be expressed as the ratio of invaded to univaded plots ( $\mathrm{I} / \mathrm{U}$ ratio). On average, this ratio was higher than 1 for all nutrients (Fig. 2), but this was only significant for $\mathrm{P}$ (I/ $\mathrm{U}=1.70)$. In contrast, concentrations of $\mathrm{NO}_{3}-\mathrm{N}$ after incubation were lower in invaded plots (I/ $\mathrm{U}=0.82$ ).

Primary productivity and nutrients in standing biomass

In all sites, aboveground biomass was significantly higher in invaded plots compared to uninvaded plots (Table 1; Fig. 3). Solidago gigantea was from $70 \%(\mathrm{Ghi})$ to $260 \%$ ( $\mathrm{Kra}$ ) more productive than the surrounding native vegetation.
The two-way ANOVA (Table 2) showed significant invasion effects for all element concentrations in plant tissues (except for $\mathrm{K}$ and $\mathrm{Zn}$ ), $\mathrm{C} /$ $\mathrm{N}$ ratio, and nutrients pools in the standing biomass (Fig. 3). Moreover, a significant 'site $\times$ invasion' interaction also existed for all nutrient concentrations and nutrient pools except for $\mathrm{Cu}, \mathrm{Zn}$ and $\mathrm{N}$, with different degree of response according to site. $t$-tests showed 11 significant differences in 45 comparisons (after Bonferroni correction) for nutrients concentrations in plant tissues. With only few exceptions, mineral nutrient concentrations in biomass were lower in invaded plots than in the resident vegetation. On average over all sites (Fig. 3), nutrient concentrations in invaded plots were $10-20 \%$ lower compared to uninvaded plots except for $\mathrm{K}$ and $\mathrm{Zn}$. C content was significantly higher in invaded plots in three sites whereas in two sites, $\mathrm{N}$ content was significantly lower compared to uninvaded plots. As a result, $\mathrm{C} / \mathrm{N}$ ratio of standing biomass was always higher in invaded plots. For nutrients pools in standing biomass, $t$-tests showed 30 significant differences on 45 comparisons (after Bonferroni correction). All significant differences consisted in greater values in invaded plots, except $\mathrm{Ca}$ in site For.

\section{Discussion}

Solidago gigantea can form monospecific stands in sites with widely different resident vegetation

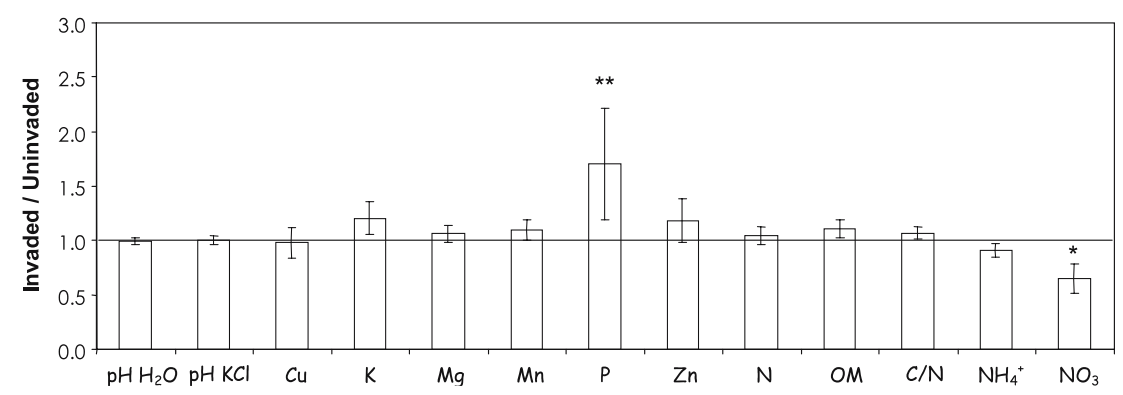

Fig. 2 Ratio of mean value of invaded plots on mean value of uninvaded plots (I/U ratio) for soil $\mathrm{pH}$, exchangeable nutrients $\left(\mathrm{mg} \mathrm{kg}^{-1}\right.$ except $\mathrm{Al}^{3+}, \mathrm{H}^{+}$: meq $100 \mathrm{~g}^{-1}$ ), organic matter (OM: \%), $\mathrm{N}$ content $(\%)$ and $\mathrm{C} / \mathrm{N}$ ratio. $\mathrm{Ca}, \mathrm{CEC}$ and $\mathrm{Bs}$ are not considered, as they were determined for $<5$ sites. Whiskers are standard errors. The horizontal line $(\mathrm{I} / \mathrm{U}=1)$ denotes equal value for invaded and uninvaded plots. Stars indicate significant invasion effect in the twoway ANOVA $(* P<0.05 ; * * P<0.01)$ 


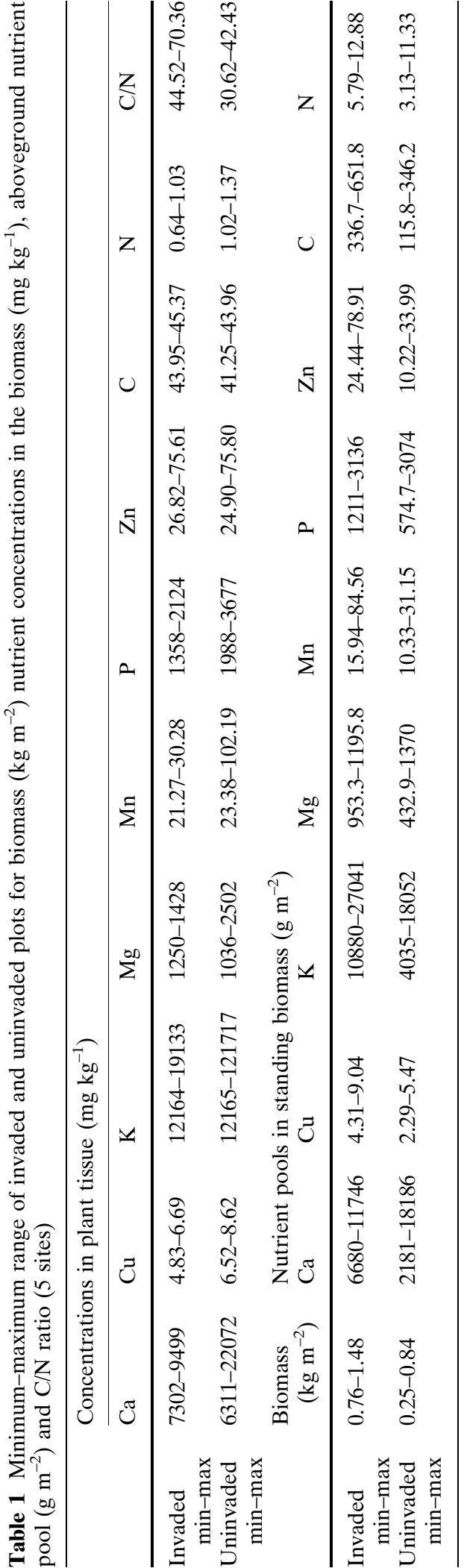

and soil chemical composition, e.g. pH ranging from 5.9 to 7.2, organic matter content from 4 to $14 \%, \mathrm{C} / \mathrm{N}$ from 12 to 22 , exchangeable $\mathrm{P}$ from 2 to $100 \mathrm{mg} \mathrm{kg}^{-1}$. This result is in line with earlier reports of a broad ecological niche of this species in Europe (Weber and Jakobs 2005). It suggests that $S$. gigantea can achieve high invasive success across a wide range of soil fertility levels. Interestingly, aboveground phytomass of invaded stands also showed a two-fold variation range roughly matching differences in soil nutrient status among sites. Thus, the site For, with the highest values of $\mathrm{P}, \mathrm{K}, \mathrm{Mg}$ and nitrate in soil, also had by far the highest productivity.

In all five sites, invaded stands had much higher aboveground productivity (on average 2.4 times higher) compared to the resident vegetation. Higher productivity in communities invaded by alien exotic plants has often been reported: Berberis thunbergii, 4-44-fold increase (Ehrenfeld et al. 2001); Lepidium latifolium, 3-fold increase (Blank and Young 2002); Phragmites australis, 3-fold increase (Windham 2001).

For all elements except for $\mathrm{Zn}$ and $\mathrm{K}$, nutrient concentrations in plant tissues were lower in invaded compared to resident vegetation. Functional differences between S. gigantea and the resident vegetation may account for this difference. Lower $\mathrm{N}$ and $\mathrm{P}$ concentrations in the standing biomass, may arguably point to higher nutrient use efficiency, defined as the amount of synthesised dry matter per unit mineral nutrients allocated to shoot (Vitousek 1982). Lower nutrient concentrations in shoots may be due to higher biomass allocation to stems, which are poor in nutrients, compared to the resident vegetation often dominated by grass-like species. Impacts of alien invasive species on element concentrations in phytomass have quite rarely been tested except for $\mathrm{C}$ and $\mathrm{N}$ content. The exotic crucifer Lepidium latifolium differed considerably from the native Elytrigia elongata with greater $\mathrm{Ca}, \mathrm{Mg}, \mathrm{K}$ and $\mathrm{S}$ content in the aboveground tissue of the invader (Blank and Young 2002), whereas Vanderhoeven et al. (2005) found lower nutrient concentrations in the biomass of Fallopia japonica, compared to the native vegetation.

However, higher productivity is not at all compensated for by lower nutrient concentrations, 


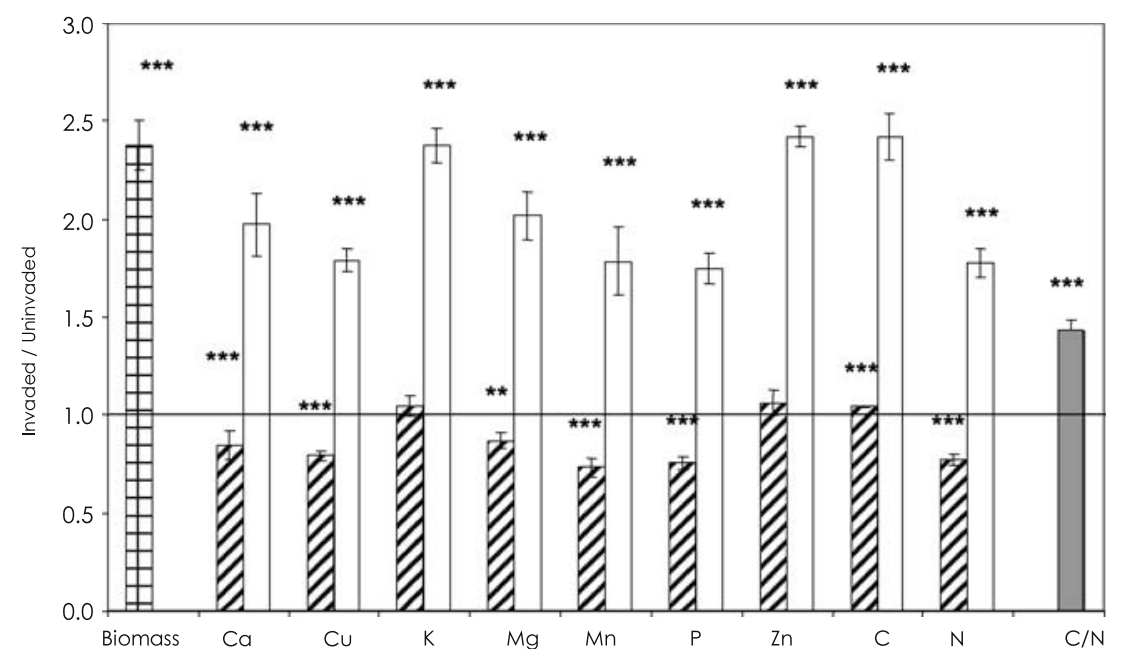

Fig. 3 Ratio of mean value of invaded plots on mean value of uninvaded plots ( $\mathrm{I} / \mathrm{U}$ ratio) for standing biomass (crossrule), nutrient concentrations in biomass (hatched), aboveground nutrient pools (white boxes) and $\mathrm{C} / \mathrm{N}$ ratio of biomass (grey box). Whiskers are standard errors. The horizontal line $(I / U=1)$ denotes equal value for invaded and uninvaded plots. Stars indicate significant invasion effect in the two-way ANOVA $(* P<0.05$; $* * P<0.01$; $* * * P<0.001)$

notable exception, with $70 \%$ higher concentrations. In three sites, significantly higher concentrations of extractable $\mathrm{P}$ were found in invaded stands. In a previous study (Vanderhoeven et al. 2005) focusing on five invasive plants, we found higher concentrations of bioavailable nutrients in the topsoil. S. gigantea was one of the five target species but the assessment of its own impact was of relative extent per se as only one site was considered. The result of this single site was however consistent with the present study performed on 5 sites as it exhibited significant differences for soil $\mathrm{P}$ and $\mathrm{pH}$ between invaded and uninvaded plots. Another recent study by Güsewell et al. (2005) was conducted in eight sites of a Swiss lakeshore wetland and focused on total soil N and P. In this ecosystem, S. gigantea was shown to be functionally similar to the resident vegetation. Our results are in agreement with their observation showing that total soil $\mathrm{N}$ concentrations under S. gigantea did not differ from those under uninvaded vegetation. However, we cannot infer about $\mathrm{P}$ status because this study assessed total $\mathrm{P}$ while we assessed more available $\mathrm{P}$ (ammonium acetate-extractable fraction).

Nutrient uplift from deep soil layers is a wellknown mechanism by which plants can increase 


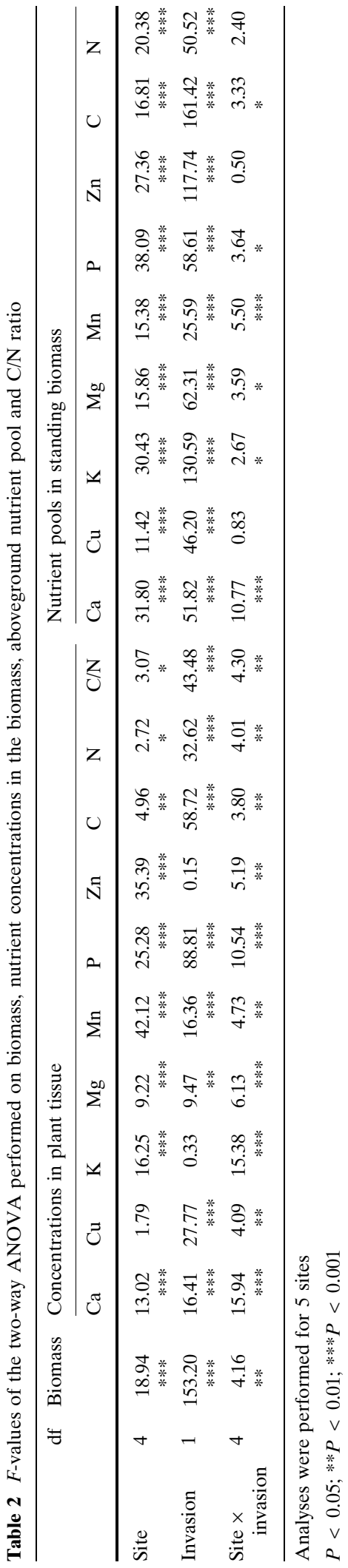

mineral nutrient concentration in topsoil (Jobbagy and Jackson 2004). However, this mechanism cannot explain the elevation of only a single nutrient, phosphorus. Moreover, S. gigantea does not seem to root considerably deeper than resident vegetation with $85 \%$ of the belowground biomass concentrated in the upper $6 \mathrm{~cm}$ vs. $80 \%$ for the resident vegetation (Dassonville et al. unpubl. obs.). Therefore, enhanced nutrient uptake rates found in S. gigantea cannot per se result in higher nutrient concentrations in topsoil. An alternative hypothesis is that S. gigantea specifically alters soil $\mathrm{P}$ availability. Recently, Chapuis-Lardy et al. (in press) found higher pools of plant available $\mathrm{P}$ (resin- and bicarbonateexchangeable) under S. gigantea. These were correlated to increased activities of phosphomonoesterase and increased soil respiration rate. The authors suggested that it may be due to enhanced soil microbial activity and/or diversity, as already observed for other invaders (Hawkes et al. 2005; Kourtev et al. 2002, 2003). Thus, enhanced $\mathrm{P}$ mineralisation rates may well be involved in the increased pools of bioavailable $\mathrm{P}$ in the topsoil. S. gigantea may also be able to use P pools that are less available for plants compared to the surrounding vegetation. The importance of mycorrhizae in the competitive ability of invasive plants has been demonstrated for Centaurea maculosa (Zabinski et al. 2002). Part of the invasive success depends on the ability of the mycorrhizal symbiont to increase tissue $\mathrm{P}$ concentrations. Jin et al. (2004) documented that the total number of arbuscular mycorrhizal fungi associated with the closely related invasive $S$. canadensis increased with time of invasion. Topsoil plant available $\mathrm{P}$ pools may also be increased as a result of increased effluxes of $\mathrm{H}^{+}$or exudation of organic acids by roots (Hinsinger 2001). This hypothesis cannot be either rejected as we observed significant acidification under $S$. gigantea compared to uninvaded plots in three sites.

The impact on soil $\mathrm{P}$ varied depending on site, as shown by the significant invasion $\times$ site interaction, with different responses (higher vs. lower $\mathrm{P}$ concentrations) and different degrees of response (from 21 to $258 \%$ higher $\mathrm{P}$ concentrations) according to site. The only exception to 
higher $\mathrm{P}$ concerned site For. This site also had by far the highest soil $\mathrm{P}$ levels prior to invasion. In this highly eutrophicated site, the resident vegetation consists of monospecific stands of Urtica dioica, a nutrient rich, highly productive species. In this single site, pools of $\mathrm{P}$ in standing biomass were similar in invaded and uninvaded plots. Varying impacts of exotics depending on site were observed for Hieracium pilosella (Scott et al. 2001), Bromus tectorum (Belnap and Philips 2001) and Centaurea maculosa (Hook et al. 2004). This suggests that environmental factors including soil nutrients and floristic composition of the invaded community may influence the response of soil to invasions (Ehrenfeld 2003).

In conclusion, our study indicated that the impact of $S$. gigantea on topsoil chemistry was quite modest with a slight increase in mineral nutrient concentrations. An essential exception was phosphorus which showed higher concentrations in invaded plots compared to uninvaded soils. Humble impacts on soil properties contrasted with the high aboveground productivity and nutrient pools of the invader. The impacts differed according to site in different responses and different degrees of response to the invasion of $S$. gigantea.

Acknowledgments This work was supported by the Belgian Science Policy and is part of the project "INPLANBEL: Invasive Plants in Belgium: Patterns, Processes and Monitoring" (contract EV/11/27C). We would like to thank W. Gruber for help with ICP-AES analyses, E. Rossi and I. Nijs (University of Antwerp) for $\mathrm{C}$ and $\mathrm{N}$ analyses, L. Chou and $\mathrm{N}$. Roevros (Free University of Brussels) for $\mathrm{NO}_{3}-\mathrm{N}$ and $\mathrm{NH}_{4}-\mathrm{N}$ analyses and A. Demoulin for logistic assistance. We would also like to thank three referees for helpful comments on a previous version of this manuscript.

\section{References}

Allison SD, Vitousek PM (2004) Rapid nutrient cycling in leaf litter from invasive plants in Hawai'i. Oecologia 141:612-619

Belnap J, Philips SL (2001) Soil biota in an ungrazed grassland: response to annual grass (Bromus tectorum) invasion. Ecol Appl 11:1261-1275

Bolton H, Smith JL, Wildung RE (1990) Nitrogen mineralization potentials of shrub-steppe soils with different disturbance histories. Soil Sci Soc Am J 54:887-891
Blank RR, Young JA (2002) Influence of the exotic invasive crucifer, Lepidium latifolium, on soil properties and elemental cycling. Soil Sci 167:821-829

Blank RR, Young JA (2004) Influence of three weed species on soil nutrient dynamics. Soil Sci 169:385397

Chapin FSI III, Matson PA, Mooney HA (2002) Principles of terrestrial ecosystem ecology. Springer Verlag, New York, pp 436

Chapuis-Lardy L, Vanderhoeven S, Dassonville N, Koutika L-S, Meerts P (in press) Effect of the exotic invasive plant Solidago gigantea on soil phosphorus status. Biol Fert Soils DOI 10.1007/s00374-005-0039-4

Ehrenfeld JG (2003) Effects of exotic plant invasions on soil nutrient cycling processes. Ecosystems 6:503-523

Ehrenfeld JG, Kourtev P, Huang W (2001) Changes in soil functions following invasions of exotic understory plants in deciduous forests. Ecol Appl 11:1287-1300

Ehrenfeld JG, Scott N (2001) Invasive species and the soil: effects on organisms and ecosystem processes. Ecol Appl 11:1259-1260

Evans RD, Rimer R, Sperry L, Belnap J (2001) Exotic plant invasions alters nitrogen dynamics in an arid grassland. Ecol Appl 1:1301-1310

Grierson PF, Adams MA (2000) Plant species affect acid phosphatase, ergosterol and microbial $\mathrm{P}$ in a Jarrah (Eucalyptus marginata Donn ex Sm.) forest in southwestern Australia. Soil Biol Biochem 32:1817-1827

Güsewell S, Zuberbühler N, Clerc C (2005) Distribution and functional traits of Solidago gigantea in a Swiss lakeshore wetland. Bot Helv 115:63-75

Hawkes CV, Wren IF, Herman DJ, Firestone MK (2005) Plant invasion alters nitrogen cycling by modifying the soil nitrifying community. Ecol Lett 8:976-985

Hinsinger P (2001) Bioavailability of soil inorganic P in the rhizosphere as affected by root-induced chemical changes: a review. Plant Soil 237:173-195

Hobbie S (1992) Effects of plant species on nutrient cycling. Trends Ecol Evol 7:336-339

Hook PB, Olson BE, Wraith JM (2004) Effects of the invasive forb Centaurea maculosa on grassland carbon and nitrogen pools in Montana, USA. Ecosystems 7:686-694

Jin L, Gu Y, Xiao M, Chen J, Li B (2004) The history of Solidago canadensis invasion and the development of its mycorrhizal associations in newly-reclaimed land. Funct Plant Biol 3:979-986

Jobbagy EG, Jackson RB (2004) The uplift of soil nutrients by plants: biogeochemical consequences across scales. Ecology 85:2380-2389

Kourtev PS, Ehrenfeld JG, Häggblom M (2003) Experimental analysis of the effect of exotic and native plant species on the structure and function of soil microbial communities. Soil Biol Biochem 35:895-905

Kourtev PS, Ehrenfeld JG, Huang WZ (2002) Enzyme activities during litter decomposition of two exotic and two native plant species in hardwood forests of New Jersey. Soil Biol Biochem 34:1207-1218

Lemée G (1967) Investigations sur la minéralisation de l'azote et son évolution annuelle dans les humus forestiers in situ. Oecologia Plantarum 2:285-323 
Levine JM, Vilà M, D'Antonio CM, Dukes JS, Grigulis K, Lavorel S (2003) Mechanisms underlying the impacts of exotic plant invasions. P Roy Soc Lond B 270: 775-778

McIntosh PD, Loeseke M, Bechler K (1995) Soil Changes under mouse-ear hawkweed (Hieracium pilosella). NZ J Ecol 19(1):29-34

Mitchell RJ, Marrs RH, Le Duc MG, Auld MHD (1997) A study of succession on lowland heaths in Dorset, southern England: changes in vegetation and soil chemical properties. J Appl Ecol 34:1426-1444

Muller S (2000) Les espèces végétales invasives en France: bilan des connaissances et propositions d'action. Revue Ecologie (Terre Vie): Suppl 7

Scott NA, Saggar S, McIntosh PD (2001) Biogeochemical impact of Hieracium invasion in New Zealand's grazed tussock grasslands: sustainability implications. Ecol Appl 11:1311-1322

StatSoft Inc. (2003) Statistica (Data analysis software) version 6. www.statsoft.com

Van Breemen N, Finzi AC (1998) Plant-soil interaction: ecological aspects and evolutionary implications. Biogeochemistry 42:1-19

Vanderhoeven S, Dassonville N, Meerts P (2005) Increased topsoil mineral nutrient concentrations under the canopy of exotic invasive plants in Belgium. Plant Soil 275:167-177

Verloove F (2002) Ingeburgerde plantensoorten in Vlaanderen. Mededeling van het Instituut voor Natuurbehoud nr. 20, Brussels
Vitousek PM (1982) Nutrient cycling and nutrient use efficiency. Am Nat 119:553-572

Wagenitz G (1964) Solidago L. In: Hegi G (ed) Illustrierte flora von Mitteleuropa, vol VI. Carl Hanser, München, pp 16-29

Walker LR, Smith SD (1996) Impacts of invasive plants on community and ecosystem properties. In: Luken JO, Thieret J (eds) Assessment and management of plant invasions. Springer-Verlag, New-York, pp 69-86

Weber E (1998) The dynamics of plant invasions: a case study of three exotic goldenrod species (Solidago L.) in Europe. J Biogeogr 24:147-154

Weber E (2003) Invasive plant species of the world: a reference guide to environmental weeds. CABI-Publishing, London, pp 548

Weber E, Jakobs G (2005) Biological flora of central Europe: Solidago gigantea Aiton. Flora 200:109-118

Weber E, Schmid B (1998) Latitudinal population differentiation in two species of Solidago (Asteraceae) introduced into Europe. Am J Bot 85:1110-1121

Windham L (2001) Comparison of biomass production and decomposition between Phragmites australis (common red) and Spartina patens (salt hay) in brackish tidal marsh of New Jersey. Wetlands 21:179-188

Zabinski CA, Quinn L, Callaway RM (2002) Phosphorus uptake, not carbon transfer, explains arbuscular mycorrhizal enhancement of Centaurea maculosa in the presence of native grassland species. Funct Ecol 16:758-765 